\title{
Hubungan Peran Pendamping dengan Partisipasi Pelaku Industri Rumahan dalam Program Pemberdayaan Perempuan di Kota Palembang
}

\section{Corelation between Community Worker Role and Participation of Home Industry Actors in Women Empowerment Program in Palembang City}

\author{
Adelia Utami ${ }^{1}$, Sriati ${ }^{2}$, Yunindyawati ${ }^{3}$ \\ ${ }^{1}$ Program Magister Sosiologi, Fakultas Ilmu Sosial dan Ilmu Politik Universitas Sriwijaya \\ ${ }^{2}$ Fakultas Pertanian Univesitas Sriwijaya \\ ${ }^{3}$ Fakultas Ilmu Sosial dan Ilmu Politik Universitas Sriwijaya
}

\begin{abstract}
Most business sectors are driven by women, especially the home industries (HI), which rely on their own abilities. Home industry is a micro scale business and commonly produces value-added goods in the homes as part time jobs. HI actors generally do not have legal business due to the ack of access to market and technology information, capital, improved human resources, institutional and network improvement, and gender sensitivity among the public. Through policies that support the development of HIs, the government provides guidance, training and assistance in the form of tools / machines provided to HI actors through women empowerment programs. The objectives of this study were to (1) examine community worker role for Household Industries, (2) assess the participation level of HIs in woman empowerment programs in Palembang City, and (3) analyze the correlation between the community worker role and the participation level of His in woman empowerment programs in Palembang City. This study used a survey method (Explanatory Survey) to analyze correlations between the study variables. The study population was HI actors - 200 people consisting of 96 people from 27 Ilir Urban Village and 104 people from 30 Ilir Urban Village. Sample was taken randomly, 32 people and 35 respectively from 27 Ilir and 30 Ilir Urban Village. The study results show that (1) community worker role for HI actors is of high category (76,60\%), (2) participation of HI actors in woman empowerment program in Palembang City is of medium level (64,35\%), (3) There is a significant correlation between the community worker role and the participation level of HI actors in woman empowerment program in Palembang City, with Spearman Correlation $R s=0.62$ with $a=0.05$.
\end{abstract}

Keywords: community worker role, participation, Household Industry, women's empowerment

\begin{abstract}
Abstrak
Sebagian besar sektor usaha banyak digerakkan oleh kaum perempuan khususnya Industri Rumahan (IR) yang memanfaatkan kemampuan mereka sendiri. Industri Rumahan adalah indutri skala mikro dan umumnya memanfaatkan atau menghasilkan produk berupa barang jadi yang memberikan nilai tambah dan dan dikerjakan di rumah secara khusus ataupun sebagai kerja paruh waktu. Pelaku IR umumnya belum memiliki legalitas usaha dikarenakan kurangnya akses informasi pasar dan teknologi, akses permodalan, peningkatan SDM, penataan kelembagaan dan jaringan serta kurangnya sensitif gender dikalangan masyarakat. Adanya kebijakan yang mendukung program dalam mendorong pembangunan IR, pemerintah memberikan bimbingan, pelatihan dan bantuan berupa alat/mesin yang diberikan kepada pelaku IR melalui program pemberdayaan perempuan. Tujuan penelitian adalah : (1) Menganalisis seberapa besar tingkat peran pendamping pelaku IR, (2) Menganalisis seberapa besar tingkat partisipasi pelaku IR dalam program pemberdayaan perempuan, dan (3) mengetahui seberapa besar hubungan antara peran pendamping dengan partisipasi pelaku IR di Kelurahan 27 Ilir dan 30 Ilir Kota Palembang. Penelitian menggunakan metode explanatory survey, dengan analisis korelasi Rank Spearman. Populasi penelitian adalah pelaku Industri Rumahan di Kelurahan 27 Ilir dan Kelurahan 30 Ilir berjumlah 200 orang, yang memiliki usaha kuliner terdiri atas 96 orang pelaku IR Kelurahan 27 Ilir dan 104 orang pelaku IR Kelurahan 30 Ilir. Sampel berjumlah 67 orang diambil secara acak, yang terdiri dari 32 pelaku IR Kelurahan 27 Ilir dan 35 pelaku IR Kelurahan 30 Ilir. Hasil penelitian adalah: (1) tingkat peran pendamping pelaku IR tergolong tinggi (76,60\%), (2) tingkat partisipasi pelaku IR tergolong sedang (64.35\%), (3) terdapat hubungan yang signifikan antara peran pendamping IR dan partisipasi pelaku IR dalam program pemberdayaan perempuan dengan nilai koefisien korelasi Rank Spearman $(\mathrm{Rs})=0,620$ pada $\mathrm{a}=0,05$.
\end{abstract}

Kata kunci: peran pendamping, partisipasi, Industri Rumahan, pemberdayaan perempuan 


\section{Pendahuluan}

Besarnya jumlah penduduk miskin timbulnya upaya penanggulangan kemiskinan yang menjadi tantangan bagi pemerintah dalam membuat suatu kebijakan, seperti pertimbangan untuk memenuhi komitmen pemerintah dalam pelaksanaan pencapaian Tujuan Pembangunan Berkelanjutan (TPB)/ Sustainable Development Goals (SDGs), pemerintah memandang perlu adanya penyelerasan dengan Rencana Pembangunan Jangka Panjang Nasional (RPJPN) dan Rencana Pembangunan Jangka Menengah Nasional (RPJMN). Lampiran Perpres Nomor 59 Tahun 2017 menguraikan tujuan global, sasaran global dan sasaran nasional RPJMN 2015-2019 yang akan dilaksanakan, yaitu disebutkan dalam tujuan ke-lima (mencapai kesetaraan gender dan memberdayakan semua perempuan dan anak perempuan). Pada tujuan ke-lima banyak memberikan perhatian terhadap pekerjaan rumahtangga dan memberikan perempuan hak yang sama terhadap sumber daya ekonomi.

Hal inilah yang mendorong pemerintah untuk mengajak perempuan berpartisipasi dalam program-program yang dikeluarkan oleh pemerintah. Layanan-layanan kemanusiaan berbasis masyarakat saat ini direfleksikan cukup banyak kebijakan dari pemerintah yang memiliki potensi perubahan progresifmaupun regresif. Kebijakan tersebut mendorong pembangunan Industri Rumahan (IR), sehingga pembangunan IR tersebut sudah diatur dalam peraturan Menteri Pemberdayaan Perempuan dan Perlindungan Anak Republik Indonesia No 2 Tahun 2016, tentang Pedoman Umum Pengembangan Industri Rumahan untuk Meningkatkan Kesejahteraan Keluarga Melalui Pemberdayaan Perempuan.

Adanya program pemberdayaan yang telah difasilitasi oleh pemerintah, tetapi masih ada saja masalah terkait partisipasi peserta dalam program pemberdayaan yang dilaksanakan. Partisipasi masyarakat masih sangat rendah karena mereka lebih memilih untuk melanjutkan pekerjaannya seperti berjualan dari pada mengikuti kegiatan yang telah direncanakan, padahal kegiatan tersebut dibuat untuk mengembangkan usaha mereka sendiri, selain itu juga karena rendahnya tingkat pendidikan pada perempuan. Partisipasi perempuan sangatlah penting dalam hal ini, karena perempuanlah yang menjadi target dari pemberdayaan yang merupakan cita-cita dalam sektor pembangunan. Adanya dorongan masyarakat untuk ikut berpartisipasi tidak terlepas dari peran pendamping yang bertugas untuk mendampingi masyarakat khususnya pelaku IR yang menjadi target pemberdayaan.

Penelitian ini perlu melihat seberapa besar tingkat peran pendamping yang bertujuan mendampingi pelaku IR, sehingga tujuan dari program yang diharapkan dapat tercapai. Seberapa jauh tujuan program tersebut dapat tercapai mencerminkan hasil kerja yang mendorong pelaku IR untuk berpartisipasi dalam kegiatan yang dilakukan oleh program pemberdayaan perempuan, karena pendamping merupakan kunci dari masyarakat tersebut untuk berpartisipasi dalam kegiatan yang dilaksanakan. Ife (2008) mengatakan bahwa pendamping harus memahami kompleksitas partisipasi, cara yang diperjuangkan dan tujuan yang berbeda yang hendak dicapai. Oleh karena itu penting dilakukan pengukuran tingkat partisipasi pelaku IR dalam program pemberdayaan perempuan yang dilakukan, serta melihat hubungan antara peran pendamping dengan partisipasi pelaku IR dalam melaksanakan program pemberdayaan perempuan berbasis Industri Rumahan.

Pemahaman konsep peran dalam penelitian ini ialah suatu tindakan dari masyarakat tidak lepas dari sistem sosial. Suatu sistem sosial didasarkan pada pluralitas para aktor individual yang berinteraksi satu sama lain dalam suatu situasi yang setidaknya mempunyai suatu aspek fisik atau lingkungan, para aktor yang termotivasi dalam kaitannya dengan tendensi ke arah "optimisasi kepuasan" dan relasi mereka dengan situasi-situasinya saling meliputi, didefinisikan dan dimediasi dalam kerangka suatu sistem simbol-simbol yang terstruktur dan dianut bersama secara budaya (Parsons dalam Ritzer, 2012:413). Definisi tersebut berusaha menggambarkan mengenai kompleks peranstatus sebagai unit dasar sistem tersebut. Kompleks itu merupakan suatu komponen struktural sistem sosial yakni, status mengacu kepada suatu posisi struktural di dalam sistem sosial dan peran adalah apa yang dilakukan aktor di dalam posisinya. Sistem memiliki fungsinya masing-masing, yang diarahkan kepada pemenuhan kebutuhan-kebutuhan dari sitem yang disebut kerangka AGIL (Adaptasi-Goal attainment- Integrasi-Latency). Penelitian ini melihat salah satu fungsi dari AGIL yaitu pada fungsi Integritas.

Peran disini merupakan bentuk dari peran pendamping 
dalam kaitanya dengan partisipasi pelaku IR dalam program pemberdayaan perempuan. Seseorang dikatakan berperan jika orang tersebut melakukan tugas/fungsinya yang sudah ditetapkan. Peran pendamping tersebut diukur melalui Tugas Pokok dan Fungsi (Tupoksi) yang sudah tertera di buku pedoman tim pendamping IR dalam program pemberdayaan perempuan yaitu: (1) persiapan sosial, (2) pembentukan dan pengembangan IR, (3) peningkatan kapasitas, dan (4) perluasan jaringan IR.

Peran pendamping juga berhubungan dengan partisipasi pelaku IR yang mana partisipasi merupakan suatu bentuk keterlibatan dan keikutsertaan pelaku IR secara aktif. Partisipasi merupakan keikutsertaan atau keterlibatan seseorang dalam suatu kelompok sosial untuk mengambil bagian dari kegiatan masyarakatnya di luar pekerjaannya (Theodorson dalam Mardikanto, 1993). Menurut Rogers dalam Levis (1996), partisipasi adalah proses pengambilan keputusan.

Dalam hal ini pengambilan keputusan memiliki pengertian yang luas, yaitu meliputi proses: perencanaan, pengambilan keputusan, pelaksanaan, evaluasi serta menikmati hasil pembangunan itu sendiri. Menurut Slamet (1994) partisipasi dalam pembangunan dapat dibedakan atas 3 tahap, yaitu: partisipasi pada tahap perencanaan, partisipasi pada tahap pelaksanaan, dan partisipasi pada tahap pemanfaatan dan evaluasi program.

Partisipasi dalam epenelitian ini diukur melalui, yaitu: (1) partisipasi dalam pengambilan keputusan, (2) partisipasi dalam pelaksanaan kegiatan, (3) partisipasi dalam pemantauan dan evaluasi pembangunan, dan (4) partisipasi dalam pemanfaatan hasil pembangunan (Yadav UNAPDI dalam Mardikanto dan Soebiato, 2013:82-84).

Penelitian terdahulu yakni mengenai Partisipasi Masyarakat dalam Program Nasional Pemberdayaan Masyarakat- Mandiri di Desa Kotabatu, Kecamatan Ciomas, Kabupaten Bogor dengan metode kuantitatif yakni metode survey dan metode kualitatif yakni metode wawancara mendalam. Responden penelitian ini berjumlah 45 orang dan dipilih secara acak. Hasil penelitian diperoleh faktor internal yang berpengaruh adalah usia dan faktor eksternal yang sangat berpengaruh adalah intensitas komunikasi. Pada program ini masyarakat kurang berpartisipasi tetapi masyarakat tetap merasakan tingkat pencapaian yang tinggi.

Tujuan penelitian ini adalah: (1) menganalisis tingkat peran pendamping pelaku Industri Rumahan, (2) menganalisis tingkat partisipasi pelaku Industri Rumahan dalam program pemberdayaan perempuan, dan (3) menganalisis hubungan antara tingkat peran pendamping dengan partisipasi pelaku Industri Rumahan dalam program pemberdayaan perempuan di Kecamatan Ilir Barat II Kota Palembang.

\section{Metode Penelitian}

Penelitian dilakukan di Kelurahan 27 Ilir dan 30 Ilir, Kecamatan Ilir Barat II Kota Palembang, Sumatera Selatan, dengan objek penelitiannya pelaku Industri Rumahan (IR) yang mengelola usaha kuliner. Metode yang digunakan adalah survey, yakni explanatory survey ialah penelitian yang bertujuan untuk menganalisis hubungan antar satu variabel dengan variabel lainnya (Umar, 1999:36).

Populasi penelitian adalah pelaku Industri Rumahan dari Kelurahan 27 Ilir dan Kelurahan 30 Ilir yang seluruhnya berjumlah 200 orang pelaku IR yang memiliki usaha kuliner dengan rincian pada pelaku IR Kelurahan 27 Ilir berjumlah 96 orang dan pelaku IR Kelurahan 30 Ilir berjumlah 104 orang. Teknik pengambilan sampel menggunakan rumus dari Taro Yamane yang dikutip oleh Riduwan (2004:65) sebagai berikut:

$$
n=\frac{N}{N \cdot d^{2}+1}
$$

Dimana :

$\mathrm{n}=$ Jumlah Sampel

$\mathrm{N}=$ Jumlah Populasi

$\mathrm{d}^{2}=$ Nilai presisi yang ditetapkan $(10 \%)$

$$
n=\frac{200}{200 \cdot 0,1^{2}+1}=\frac{200}{3}=66,6 \approx 67
$$

Jadi, jumlah sampel sebanyak 67 orang pelaku Industri Rumahan yang diambil secara proporsional dari 2 kelurahan, sehingga diperoleh 32 responden dari Kelurahan 27 Ilir dan 35 responden dari Kelurahan 30 Ilir. 
Variabel penelitian meliputi peran pendamping IR dan partisipasi pelaku IR. Tingkat peran pendamping adalah pelaksanaan peran pendamping dalam program Industri Rumahan, diukur berdasarkan tugas pokok dan fungsi (tupoksi) pendamping IR yang meliputi 4 aspek, yaitu: (1) persiapan sosial, (2) pembentukan dan pengembangan jaringan IR, (3) peningkatan kapasitas, dan (4) perluasan jaringan sosial.

Tingkat Partisipasi dalam Program Industri rumahan adalah keikutsertaan pelaku IR dalam setiap tahap kegiatan program Industri Rumahan. Tingkat partisipasi pelaku IR diukur melalui 4 tahap, yaitu tahap (1) pengambilan keputusan, (2) pelaksanaan kegiatan, (3) dan evaluasi pembangunan, dan (4) pemanfaatan hasil pembangunan. Setiap variabel diukur melalui indikatornya yang mana setiap indikator terdiri dari beberapa item pertanyaan sesuai dengan makna konsepnya.

Untuk variabel peran pendamping terdiri dari 4 aspek, 8 indikator dan 30 pertanyaan. Sementara variabel partisipasi pelaku IR terdiri dari 4 aspek (dimensi), 7 indikator dan 16 pertanyaan. Secara terinci indikator variabel peran pendamping dan pertisipasi pelaku IR diperlihatkan pada Tabel 1.

Selanjutnya item pertanyaan diukur dengan pemberian skor 1, 2 dan 3 yang merepresentasikan capaian rendah, sedang, dan tinggi. Total jawaban terhadap indikator/ variabel dikatagorikan dalam 3 tingkatan/kriteria berdasarkan rumus interval kelas, dan nilai kriteria setiap indikator diperlihatkan pada Tabel 2.

Data yang dikumpulkan terdiri atas data primer dan data sekunder. Data primer meliputi data tentang karakteristik pelaku IR, peran pendamping dan partisipasi pelaku IR, sementara data sekunder meliputi dokumen pendukung, baik dari instansi pemerintah maupun non pemerintah yang relavan dengan penelitian.

Data dianalisis secara deskriptif dan dengan statistik inferensial menggunakan statistik non parametrik. Untuk menganalisis hubungan antar variabel dilakukan dengan uji koefisien korelasi Rank Spearman.

Tabel 1. Indikator Variabel Peran Pendamping dan Partisipasi Pelaku IR

\begin{tabular}{|c|c|c|c|}
\hline Variabel & Dimensi & Indikator & Pertanyaan \\
\hline \multirow[t]{4}{*}{$\begin{array}{l}\text { Peran } \\
\text { Pendamping } \\
\text { (X) }\end{array}$} & 1. Persiapan Sosial & $\begin{array}{l}\text { a. Adanya kegiatan orientasi atau pengenalan } \\
\text { program } \\
\text { b. Adanya kegiatan sosialisasi yang dilakukan } \\
\text { pendamping }\end{array}$ & $6-8$ \\
\hline & $\begin{array}{l}\text { 2. Pembentukan dan } \\
\text { Pengembangan Jaringan } \\
\text { IR }\end{array}$ & $\begin{array}{l}\text { a. Pembentukan pertemuan awal dengan pelaku IR } \\
\text { b. Pertemuan lanjutan } \\
\text { c. Pendampingan secara individu ke pelaku IR }\end{array}$ & $\begin{array}{r}9-14 \\
15-17 \\
18-21\end{array}$ \\
\hline & 3. Peningkatan Kapasitas & $\begin{array}{l}\text { a. Mampu memberikan pelatihan kewirausahaan } \\
\text { b. Mampu memfasilitasi pelatihan teknis dan } \\
\text { keterampilan usaha }\end{array}$ & $\begin{array}{r}22-24 \\
25-26\end{array}$ \\
\hline & 4. Perluasan Jaringan IR & $\begin{array}{l}\text { a. Mampu memfasilitasi jaringan IR atau } \\
\text { menghubungkan jaringan IR }\end{array}$ & $27-30$ \\
\hline \multirow[t]{5}{*}{$\begin{array}{l}\text { Partisipasi } \\
\text { Pelaku IR (Y) }\end{array}$} & $\begin{array}{l}\text { 1. Partisipasi dalam } \\
\text { pengambilan keputusan }\end{array}$ & $\begin{array}{l}\text { a. Keterlibatan masyarakat dalam pemanfaatan } \\
\text { sumber daya lokal }\end{array}$ & $1-3$ \\
\hline & & b. Partisipasi masyarakat dalam forum masyarakat & $4-5$ \\
\hline & $\begin{array}{l}\text { 2. Partisipasi dalam } \\
\text { pelaksanaan kegiatan }\end{array}$ & $\begin{array}{l}\text { a. Mengikuti pelaksanaan program } \\
\text { b. Memberikan beragam bentuk bantuan }\end{array}$ & $\begin{array}{l}6-7 \\
8-9\end{array}$ \\
\hline & $\begin{array}{l}\text { 3. Partisipasi dalam } \\
\text { pemantauan dan evaluasi } \\
\text { pembangunan }\end{array}$ & $\begin{array}{l}\text { 1. Mampu mengumpulkan informasi } \\
\text { 2. Mampu memantau dan mengevaluasi masalah } \\
\text { dan kendala yang dialami }\end{array}$ & $\begin{array}{l}10-11 \\
12-13\end{array}$ \\
\hline & $\begin{array}{l}\text { 4. Partisipasi dalam } \\
\text { pemanfaatan hasil } \\
\text { pembangunan }\end{array}$ & $\begin{array}{l}\text { 1. Mampu memperbaiki mutu hidup masyarakat } \\
\text { dan memberikan manfaat }\end{array}$ & $14-16$ \\
\hline
\end{tabular}


Tabel 2. Nilai Interval Kelas untuk Mengukur Variabel Peran Pendamping dan Partisipasi Pelaku IR

\begin{tabular}{|c|c|c|c|c|c|c|c|c|c|}
\hline \multirow{2}{*}{ No } & \multirow{2}{*}{ Variabel/Indikator } & \multirow{2}{*}{$\begin{array}{l}\text { Item } \\
\text { Pert. }\end{array}$} & \multirow{2}{*}{ Min } & \multirow{2}{*}{$\operatorname{Max}$} & \multirow{2}{*}{ NR } & \multirow{2}{*}{ PI } & \multicolumn{3}{|c|}{ Kriteria } \\
\hline & & & & & & & $\mathbf{R}$ & $\mathbf{S}$ & $T$ \\
\hline 1. & Peran Pendamping & 30 & 30 & 150 & 120 & 40 & $30-70$ & $71-110$ & $111-150$ \\
\hline a. & Persiapan Sosial & 8 & 8 & 40 & 32 & 11 & $8-18$ & $19-29$ & $30-40$ \\
\hline b. & $\begin{array}{l}\text { Pembentukan dan Pengembangan } \\
\text { Jaringan IR }\end{array}$ & 13 & 13 & 65 & 52 & 17 & $13-30$ & $31-47$ & $48-65$ \\
\hline c. & Peningkatan Kapasitas & 5 & 5 & 25 & 21 & 7 & $5-11$ & $12-18$ & $19-25$ \\
\hline $\mathrm{d}$. & Perluasan Jaringan IR & 4 & 4 & 20 & 17 & 6 & $4-9$ & $10-14$ & $15-20$ \\
\hline 2. & Partisipasi Pelaku IR & 16 & 16 & 80 & 64 & 21 & $16-37$ & $38-59$ & $60-80$ \\
\hline a. & Partisipasi dalam pengambilan keputusan & 5 & 5 & 25 & 20 & 7 & $5-11$ & $12-18$ & $19-25$ \\
\hline b. & Partisipasi dalam pelasnaan kegiatan & 4 & 4 & 20 & 16 & 5 & $4-9$ & $10-14$ & $15-20$ \\
\hline c. & $\begin{array}{l}\text { Partisipasi dalam pemantauan dan } \\
\text { evaluasi }\end{array}$ & 4 & 4 & 20 & 16 & 5 & $4-9$ & $10-14$ & $15-20$ \\
\hline d. & Partisipasi dalam pemanfaatan hasil & 3 & 3 & 15 & 12 & 4 & $3-6$ & $7-10$ & $11-15$ \\
\hline
\end{tabular}

\section{Hasil dan Pembahasan}

\section{Karakteristik Responden}

Responden dalam penelitian ini adalah pelaku Industri Rumahan (IR) pada program pemberdayaan perempuan Dinas PPPAPM Kota Palembang, yaitu 67 orang. Karakteritik demografi responden meliputi tempat tinggal, umur, pendidikan, lama usaha, pendapatan IR. Dimana pelaku IR yang bertempat tinggal di Kelurahan 27 Ilir sebanyak 32 orang atau 48\% (persen), sedangkan pelaku IR yang bertempat tinggal di Kelurahan $30 \mathrm{Ilir}$ sebanyak 35 orang atau 52\% (persen).

Pelaku IR berjualan di rumah mereka masing-masing atau disekitar lingkungan tempat tinggal mereka. Umur responden berkisar dari 22 sampai 70 dengan rata-rata 44,5 tahun. Berdasarkan tingkat pendidikan responden berkisar dri SD sampai SMA, dan kelompok tersebar adalah SMA (49\%).

Berdasarkan lama usahanya, responden berkisar dari 1 sampai 25 tahun, dengan rata-rata 8 tahun, dan sebagian besar (82\%) berusaha 1-10 tahun. Pendapatan Responden dari usaha kuliner (IR) berkisar dari Rp.500.000,- sampai Rp. 6.000.000,- dengan rata-rata Rp. 1.929.851,- per bulan. Data berdasarkan jumlah tanggungan keluarga IR, berkisar dari 0 sampai 6 orang dan rata-rata 3 orang. Gambaran terinci tentang karakteristik responden diperlihatkan pada Tabel 3.

\section{Peran Pendamping}

Peran adalah suatu perilaku yang diharapkan dari seseorang yang mempunyai suatu status tertentu, karena setiap orang memiliki sejumlah status yang diharapkan untuk mengisi setiap status tersebut (Horton dan Hunt, 1991:118). Pendamping disiniadalah kaderyang ditunjuk oleh Dinas PPPAPM Kota Palembang sesuai wilayah binaan yang ditunjuk. Pendampingan diperlukan untuk mengawal, memberikan konsultasi dan bantuan teknis dalam menindaklanjuti pengembangan kapasitas pelaku

Tabel 3. Distribusi Responden berdasarkan Karakteristik Demografi

\begin{tabular}{llrr}
\hline \multicolumn{1}{c}{$\begin{array}{c}\text { Karak } \\
\text { teristik }\end{array}$} & \multicolumn{1}{c}{ Kriteria } & Jumlah & Persentase \\
\hline Umur(tahun) & $12-25$ & 2 & 2,98 \\
& $26-45$ & 32 & 47,76 \\
& $46-65$ & 32 & 47,46 \\
& $65-70$ & 1 & 1,40 \\
Pendidikan & SD & 11 & 16,42 \\
& SMP/sederajat & 23 & 34,33 \\
& SMA/sederajat & 33 & 49,25 \\
Lama usaha & $1-10$ & 55 & 82,09 \\
(tahun) & $11-20$ & 8 & 11,94 \\
& $>20$ & 4 & 5,97 \\
Pendapatan & & 19 & 28,35 \\
dari Industri & $1.100 .000-1.500 .000$ & 16 & 23,88 \\
Rumahan & $1.600 .000-2.000 .000$ & 13 & 19,40 \\
(Rp/bln) & $2.100 .000-2.500 .000$ & 4 & 5,97 \\
& $2.600 .000-3.000 .000$ & 12 & 17,91 \\
& $3.100 .000-6.000 .000$ & 3 & 4,77 \\
\hline
\end{tabular}


IR terkait pengembangan produk, perencanaan produksi, kualitas dan manajemen usaha serta keuangan sehingga kualitas produk IR yang dihasilkan lebih baik dengan produktivitas lebih tinggi dibandingkan sebelumnya. Peran pendamping diukur dari Tupoksi yang diberikan oleh Dinas PPPAPM Kota Palembang, yang diukur melalui 4 indikator yaitu persiapan sosial, pembentukan dan pengembangan jaringan IR, peningkatan kapasitas pelaku IR dan memperluas jaringan IR. Indikator tersebut diukur menggunakan kuisioner yang telah disiapkan peneliti, yakni dengan pemberian skor terhadap setiap indikator. Hasil Penelitian menunjukkan bahwa peran pendamping termasuk dalam katagori tinggi dengan skor rata-rata 115 (capaian 76,67\%). Skor rata-rata dari pengukuran setiap indikator tingkat peran pendamping dapat dilihat pada Tabel 4.berikut.

Tabel 4. Skor Rata-rata Per-Indikator Variabel Peran Pendamping

\begin{tabular}{|c|c|c|c|c|}
\hline No & Indikator & $\begin{array}{c}\text { Skor } \\
\text { Capaian }\end{array}$ & $\begin{array}{l}\text { Rata- } \\
\text { rata }\end{array}$ & Kriteria*) \\
\hline 1 & Persiapan Sosial & 1.840 & 27 & Sedang \\
\hline 2 & $\begin{array}{l}\text { Pembentukan dan } \\
\text { Pengembangan } \\
\text { Jaringan IR }\end{array}$ & 3.483 & 52 & Tinggi \\
\hline 3 & Peningkatan Kapasitas & 1.349 & 20 & Tinggi \\
\hline 4 & Perluasan Jaringan IR & 1.026 & 15 & Tinggi \\
\hline \multicolumn{2}{|c|}{ Total Peran Pendampaing } & 7.698 & 115 & Tinggi \\
\hline
\end{tabular}

${ }^{*}$ Kriteria mengacu pada Tabel 2

Dari Tabel 4 terlihat bahwa semua indikator peran pendamping termasuk kriteria tinggi, kecuali pada indikator persiapan sosial yang termasuk kriteria sedang. Kuisioner pada variabel peran pendamping terdiri dari 30 butir pertanyaan dan dijawab oleh 67 responden. Pada tiap-tiap butir disediakan jawaban dengan skor berjenjang 1-5. Berikut peneliti deskripsikan jumlah skor yang dicapai untuk tiap-tiap butir pernyataan untuk variabel peran pendamping seperti pada Tabel 5.

Berdasarkan pengukuran tingkat peran pendamping memiliki empat indikator yang setiap indikatornya diukur melalui jawaban responden yang didapatkan melalui kuisioneryang telah diberikan. Indikator pertama yakni mengenai persiapan sosial memperoleh skor 1.840 dengan rata-rata sebesar 27 dimana didapatkan persentase sebesar 69\% tergolong dalam kriteria sedang. Artinya pendamping belum berperan secara maksimal dalam memahami tugas, fungsi, dan metode yang akan dilakukan dari program yang ditangani, serta sosialisasi program kepada pelaku IR masih tergolong sedang, terbukti dari pernyataan yang diberikan oleh beberapa pelaku IR yang menyatakan bahwa mereka belum pernah mendapatkan sosialisasi tersebut,sehingga mereka hanya mengikuti saja ajakan dari pendamping tanpa mengetahui apa sebenarnya tujuan program yang dilaksanakan. Hal tersebut dapat dilihat dari skor item pertanyaan nomor 8 dengan rata-rata 1,9 masuk dalam kriteria rendah.

Indikator kedua yakni mengenai pembentukan dan pengembangan jaringan IR dengan tiga tahap yaitu pendamping mengadakan pertemuan awal dengan seluruh pelaku IR, kemudian dilanjutkan dengan pertemuan lanjutan dan melakukan pendampingan secara individu kepada pelaku IR tersebut. Indikator ini memperoleh skor 3.483 dengan rata-rata 52 dimana didapatkan persentase sebesar $80 \%$ tergolong dalam kriteria tinggi. Artinya pendamping sudah berperan secara maksimal dalam melakukan kunjungan atau pendekatan terhadap pelaku IR untuk saling mengenal, membangun jaringan komunikasi dan kerjasama kepada pelaku IR, serta pendamping sudah melakukan tugasnya dengan baik untuk mengetahui lebih dalam tentang usaha yang dikembangkan oleh masing-masing pelaku IR yang bersangkutan. Sehingga pelaku IR dapat leluasa menceritakan pengalaman dan masalah atau kendalakendala yang mereka hadapai dalam peningkatan kualitas usahanya. Walaupun masih ada dua item pertanyaan yang masuk kedalam kriteria sedang yaitu pada nomor 10 dan 15 mengenai pelaku IR belum diberikan kesempatan menjadi koordinator pada setiap kegiatan dan jarangnya pelaku IR diberikan kesempatan untuk menceritakan pengalaman terkait usaha yang sedang mereka jalani.

Indikator ketiga yakni mengenai peningkatan kapasitas IR memperoleh skor 1.349 dengan rata-rata 20 dimana didapatkan persentase sebesar $81 \%$ tergolong dalam kriteria tinggi. Artinya pendamping sudah berperan secara maksimal dalam melakukan pendampingannya sebagai fasilitator kegiatan yang dilaksanakan seperti diadakannya pelatihan kewirausahaan, pelatihan teknis dan keterampilan usaha. Sebagaian besar pelaku IR mengikuti kegiatan-kegiatan yang diadakan oleh Dinas PPPAPM Kota Palembang, hal ini tidak terlepas dari dorongan pendamping kepada pelaku IR agar 
Tabel 5. Skor Peran Pendamping IR

\begin{tabular}{|c|c|c|c|c|c|c|c|c|c|}
\hline \multirow{2}{*}{$\begin{array}{c}\text { Item } \\
\text { Pertanyaan }\end{array}$} & \multicolumn{5}{|c|}{ Jawaban Responden } & \multirow{2}{*}{$\begin{array}{l}\text { Skor } \\
\text { Total }\end{array}$} & \multirow{2}{*}{ Rata- rata } & \multirow{2}{*}{$\begin{array}{c}\text { Capaian } \\
\left.(\%)^{*}\right)\end{array}$} & \multirow{2}{*}{$\begin{array}{l}\text { Kriteria } \\
\text { Capaian }\end{array}$} \\
\hline & 1 & 2 & 3 & 4 & 5 & & & & \\
\hline 1 & 5 & 1 & 10 & 33 & 18 & 259 & 3.9 & $77 \%$ & Tinggi \\
\hline 2 & 4 & 0 & 8 & 33 & 22 & 270 & 4.0 & $81 \%$ & Tinggi \\
\hline 3 & 4 & 2 & 7 & 26 & 28 & 273 & 4.1 & $81 \%$ & Tinggi \\
\hline 4 & 6 & 4 & 7 & 30 & 20 & 255 & 3.8 & $76 \%$ & Tinggi \\
\hline 5 & 7 & 2 & 9 & 34 & 15 & 249 & 3.7 & $74 \%$ & Sedang \\
\hline 6 & 13 & 4 & 10 & 31 & 9 & 220 & 3.3 & $66 \%$ & Sedang \\
\hline 7 & 21 & 7 & 15 & 18 & 6 & 182 & 2.7 & $54 \%$ & Sedang \\
\hline 8 & 39 & 8 & 6 & 11 & 3 & 132 & 1.9 & $39 \%$ & Rendah \\
\hline \multicolumn{6}{|c|}{ Jumlah } & 1.840 & 27.0 & $69 \%$ & Sedang \\
\hline 9 & 0 & 6 & 15 & 29 & 17 & 258 & 3.8 & $77 \%$ & Tinggi \\
\hline 10 & 19 & 10 & 17 & 15 & 6 & 180 & 2.6 & $54 \%$ & Sedang \\
\hline 11 & 4 & 3 & 5 & 38 & 17 & 262 & 3.9 & $78 \%$ & Tinggi \\
\hline 12 & 2 & 0 & 15 & 23 & 27 & 274 & 4.0 & $82 \%$ & Tinggi \\
\hline 13 & 0 & 1 & 7 & 23 & 36 & 295 & 4.4 & $88 \%$ & Tinggi \\
\hline 14 & 0 & 1 & 6 & 32 & 28 & 288 & 4.3 & $86 \%$ & Tinggi \\
\hline 15 & 13 & 6 & 18 & 24 & 6 & 205 & 3.1 & $61 \%$ & Sedang \\
\hline 16 & 1 & 1 & 1 & 39 & 25 & 287 & 4.3 & $86 \%$ & Tinggi \\
\hline 17 & 0 & 3 & 2 & 27 & 35 & 295 & 4.4 & $88 \%$ & Tinggi \\
\hline 18 & 0 & 4 & 2 & 29 & 32 & 290 & 4.3 & $87 \%$ & Tinggi \\
\hline 19 & 0 & 1 & 7 & 36 & 23 & 282 & 4.2 & $84 \%$ & Tinggi \\
\hline 20 & 0 & 1 & 4 & 34 & 28 & 290 & 4.3 & $87 \%$ & Tinggi \\
\hline 21 & 0 & 3 & 5 & 39 & 20 & 277 & 4.1 & $83 \%$ & Tinggi \\
\hline \multicolumn{6}{|c|}{ Jumlah } & 3.483 & 52.0 & $80 \%$ & Tinggi \\
\hline 22 & 0 & 5 & 5 & 36 & 21 & 274 & 4.1 & $82 \%$ & Tinggi \\
\hline 23 & 1 & 1 & 4 & 43 & 18 & 277 & 4.1 & $83 \%$ & Tinggi \\
\hline 24 & 2 & 3 & 11 & 37 & 14 & 259 & 3.9 & $77 \%$ & Tinggi \\
\hline 25 & 1 & 0 & 10 & 36 & 20 & 275 & 4.1 & $82 \%$ & Tinggi \\
\hline 26 & 7 & 4 & 6 & 19 & 31 & 264 & 3.9 & $79 \%$ & Tinggi \\
\hline \multicolumn{6}{|c|}{ Jumlah } & 1.349 & 20 & $81 \%$ & Tinggi \\
\hline 27 & 2 & 0 & 6 & 40 & 19 & 275 & 4.1 & $82 \%$ & Tinggi \\
\hline 28 & 1 & 5 & 3 & 42 & 16 & 268 & 4.0 & $80 \%$ & Tinggi \\
\hline 29 & 6 & 4 & 14 & 30 & 13 & 241 & 3.6 & $72 \%$ & Sedang \\
\hline 30 & 5 & 6 & 13 & 29 & 14 & 242 & 3.6 & $72 \%$ & Sedang \\
\hline \multicolumn{6}{|c|}{ Jumlah } & 1.026 & 15.0 & $77 \%$ & Tinggi \\
\hline Skor Total & 163 & 96 & 248 & 916 & 587 & 7.698 & 115.0 & $77 \%$ & Tinggi \\
\hline
\end{tabular}

Sumber : Diolah dari data primer (2018)

Keterangan: $\quad{ }^{*}(\%)$ diukur dari skor total/skor ideal

${ }^{*}$ Skor ideal $5 \times 67=335$

pelaku IR dapat meluangkan waktu berjualannya IR memperoleh skor 1.026 denganrata-rata 15 dimana sebentar untuk mengikuti kegiatan yang dilaksanakan. didapatkan persentase sebesar $77 \%$ tergolong dalam Indikator keempat yakni mengenai perluasan jaringan kriteria tinggi. Artinya pendamping sudah berperan 
secara maksimal dalam melakukan pendampingannya dalam memperluas jaringan IR dengan mengajak pelaku IR untuk mengikuti pameran produk usaha yang biasanya diadakan oleh instansi terkait. Pameran yang diikuti menjadi wadah untuk pelaku IR dalam memperkenalkan produk yang mereka jual dan pelaku IR juga mendapatkan pengalaman, sehingga mereka mampu untuk bersaing dipasar. Meskipun masih ada dua item pertanyaan yang masuk dalam kriteria sedang yaitu pada nomor 29 dan 30 yakni mengenai kurangnya kesempatan yang diberikan oleh fasilitator untuk pelaku IR bekerjasama dengan pihak pemerintah maupun swasta dalam memasarkan produk yang dijual.

\section{Tingkat Partisipasi Pelaku Industri Rumahan (IR)}

Partisipasi pelaku IR adalah suatu keterlibatan pelaku IR dalam memberikan respon terhadap kegiatan yang dilaksanakan dalam mendukung pencapaian tujuan program. Bagi pelaku IR, kemauan berusaha terkait dengan isu keadilan gender. Mereka dipengaruhi pelabelan yang diberikan kepada perempuan sebagai ibu rumah tangga, bukan pekerja atau pelaku usaha, walaupun sesungguhnya sebagian besar mereka merupakan pelaku usaha dan berkontribusi pada peningkatan kesejahteraan keluarga dan lingkungan. Kondisi ini berpengaruh pada pada sikap dan perilaku dalam memperlakukan usahanya, seperti pengalokasian waktu, tenaga dan perhatian terhadap usaha. Perempuan pelaku IR sering dikalahkan kepentingan lain yang berkaitan dengan kepentingan rumah tangga dan kegiatan sosial. Tingkat partisipasi pelaku IR diukur melalui 4 tahapan yaitu partisipasi dalam pengambilan keputusan, partisipasi dalam pelaksanaan kegiatan, partisipasi dalam pemantauan dan evaluasi

Tabel 6. Skor Rata-rata Tingkat Partisipasi Pelaku IR

\begin{tabular}{|c|c|c|c|c|}
\hline No & Indikator & $\begin{array}{c}\text { Skor } \\
\text { Capaian }\end{array}$ & $\begin{array}{l}\text { Rata- } \\
\text { rata }\end{array}$ & Kriteria*) \\
\hline 1 & $\begin{array}{l}\text { Partisipasi dalam } \\
\text { Pengambilan } \\
\text { Keputusan }\end{array}$ & 1.076 & 16 & Sedang \\
\hline 2 & $\begin{array}{l}\text { Partisipasi dalam } \\
\text { Pelaksanaan Kegiatan }\end{array}$ & 938 & 14 & Sedang \\
\hline 3 & $\begin{array}{l}\text { Partisipasi dalam } \\
\text { Pemantauan Evaluasi } \\
\text { Pembangunan }\end{array}$ & 642 & 10 & Sedang \\
\hline 4 & $\begin{array}{l}\text { Partisipasi dalam } \\
\text { Pemanfaatan Hasil } \\
\text { Pembangunan }\end{array}$ & 793 & 12 & Tinggi \\
\hline & Total Partisipasi & 3.449 & 51 & Sedang \\
\hline
\end{tabular}

pembangunan dan partisipasi dalam pemanfaatan hasil pembangunan. Hasil pengukuran tingkat partisipasi pelaku IR dapat dilihat pada Tabel 6.

Dari Tabel 6, dapat diketahui bahwa tingkat partisipasi pelaku IR berada pada kriteria sedang dengan skor total 3.449 rata-rata 51 (capaian 63,75\%). Bila dilihat dari setiap indikator tampak bahwa semua indikator tahapan partisipasi termasuk kriteria sedang kecuali pada partisipasi pada pemanfaatan hasil pembangunan yang termasuk riteria tinggi, dengan capaian skor sebesar 793 atau rata-rata 12 (capaian 80\%) termasuk kriteria tinggi. Kuisioner pada variabel partisipasi pelaku IR terdiri dari 16 item pernyataan. Deskripsi terinci tentang jawaban responden terhadap setiap item pertanyaan tersebut diperlihatkan pada Tabel 7.

Berdasarkan pengukuran tingkat partisipasi pelaku IR memiliki empat tahapan yang setiap tahapannya diukur melalui jawaban responden yang didapatkan melalui kuisioner yang telah diberikan. Tahapan pertama yakni mengenai partisipasi dalam pengambilan keputusan memperoleh skor 1.076 dengan rata-rata 51 dimana didapatkan persentase sebesar $64 \%$ tergolong dalam kriteria sedang. Artinya pelaku IR belum berpartisipasi aktif dalam pengambilan keputusan program. Padahal partisipasi pelaku IR perlu diikutsertakan dalam hal ini, karena pelaku IR lah yang lebih tahu kebutuhan mereka dibandingkan program yang telah ditetapkan sendiri oleh pemerintah pusat yang hanya mencerminkan kebutuhan kelompok elit-elit kecil yang berkuasa dan kurang mencerminkan kebutuhan masyarakat banyak. Indikator dalam setiap item pertanyaan tersebut hanya satu pertanyaan yang respondennya menjawab tinggi yaitu pada item nomor 2 yaitu pelaku IR mengikuti kegiatan-kegaiatan dalam program yang diberikan oleh Dinas PPPAPM Kota Palembang. Sedangkan item pertanyaan yang terendah yaitu pada item nomor 3 mengenai pelaku IR tidak pernah mengikuti pengambilan keputusan dalam alokasi dana karena hal tersebut bersifat rahasia negara.

Tahap kedua yakni partisipasi dalam pelaksanaan kegiatan. Tahapan ini memperoleh skor 938 dengan rata-rata 14 dimana didapatkan persentase sebesar 70\% tergolong dalam kriteria sedang. Artinya pendamping sudah mendorong pelaku IR agar ikut berpartisipasi dalam kegiatan yang dilaksanakan,akan tetapi masih ada pelaku IR yang masih pasif dalam kegiatan tersebut, 
Tabel 7. Distribusi Jawaban Responden tentang Tingkat Partisipasi

\begin{tabular}{|c|c|c|c|c|c|c|c|c|c|}
\hline \multirow{2}{*}{$\begin{array}{c}\text { Item } \\
\text { Pertanyaan }\end{array}$} & \multicolumn{5}{|c|}{ Jawaban Responden } & \multirow{2}{*}{ Skor Total } & \multirow{2}{*}{ Rata- rata } & \multirow{2}{*}{ Capaian (\%) } & \multirow{2}{*}{ Kriteria } \\
\hline & 1 & 2 & 3 & 4 & 5 & & & & \\
\hline 1 & 4 & 2 & 48 & 148 & 45 & 247 & 3.7 & $74 \%$ & Sedang \\
\hline 2 & 0 & 10 & 36 & 140 & 75 & 261 & 3.9 & $78 \%$ & Tinggi \\
\hline 3 & 32 & 14 & 48 & 24 & 30 & 148 & 2.2 & $44 \%$ & Rendah \\
\hline 4 & 7 & 2 & 42 & 104 & 95 & 250 & 3.7 & $75 \%$ & Sedang \\
\hline 5 & 28 & 4 & 45 & 68 & 25 & 170 & 2.5 & $51 \%$ & Sedang \\
\hline \multicolumn{6}{|c|}{ Jumlah } & 1.076 & 16 & $64 \%$ & Sedang \\
\hline 6 & 1 & 4 & 21 & 168 & 75 & 269 & 4.0 & $80 \%$ & Tinggi \\
\hline 7 & 4 & 14 & 72 & 100 & 35 & 225 & 3.4 & $67 \%$ & Sedang \\
\hline 8 & 16 & 16 & 33 & 72 & 70 & 207 & 3.1 & $62 \%$ & Sedang \\
\hline 9 & 17 & 2 & 3 & 100 & 115 & 237 & 3.5 & $71 \%$ & Sedang \\
\hline \multicolumn{6}{|c|}{ Jumlah } & 938 & 14 & $70 \%$ & Sedang \\
\hline 10 & 25 & 16 & 27 & 52 & 60 & 180 & 2.7 & $54 \%$ & Sedang \\
\hline 11 & 17 & 10 & 75 & 68 & 15 & 185 & 2.8 & $55 \%$ & Sedang \\
\hline 12 & 30 & 22 & 30 & 64 & 0 & 146 & 2.2 & $44 \%$ & Rendah \\
\hline 13 & 41 & 8 & 36 & 16 & 30 & 131 & 2.0 & $39 \%$ & Rendah \\
\hline \multicolumn{6}{|c|}{ Jumlah } & 642 & 10 & $48 \%$ & Sedang \\
\hline 14 & 3 & 10 & 15 & 128 & 110 & 266 & 4.0 & $79 \%$ & Tinggi \\
\hline 15 & 0 & 6 & 21 & 148 & 100 & 275 & 4.1 & $82 \%$ & Tinggi \\
\hline 16 & 1 & 6 & 51 & 144 & 50 & 252 & 3.8 & $75 \%$ & Tinggi \\
\hline \multicolumn{6}{|c|}{ Jumlah } & 793 & 12 & $79 \%$ & Tinggi \\
\hline Skor Total & 226 & 146 & 603 & 1.544 & 930 & 3.449 & 51 & $64 \%$ & Sedang \\
\hline
\end{tabular}

mereka hanya mengikuti kegiatan yang sudah ditetapkan dan setelah kegiatan berlangsung pelaku IR belum menerapkan apa yang mereka dapatkan selama pelatihan. Terlihat dari kurangnya respon dalam bertanya antara pelaku IR dengan narasumber yang telah memberikan materi kegiatan.

Tahap ketiga yakni partisipasi dalam pemantauan dan evaluasi pembangunan memperoleh skor 642 dengan rata-rata 10 dimana didapatkan persentase sebesar 48\% tergolong dalam kriteria sedang. Kegiatan pemantauan dan evaluasi program pembangunan sangat diperlukan. Partisipasi pelaku IR dalam hal ini untuk mengumpulkan informasi yang berkaitan dengan perkembangan kegiatan. Tetapi dalam hal ini pelaku IR tidak diberikan kesempatan dalam penilaian program yang dilaksanakan dan hanya saja pelaku IR terkadang masih aktif dalam mencari informasi sendiri mengenai kegiatan keberlanjutan, terlihat pada item pertanyaan nomor 12 dan 13 yang masuk dalam kriteria rendah.
Tahap keempat yakni partisipasi dalam pemanfaatan hasil pembangunan memperoleh skor 793 dengan rata-rata 12 dimana didapatkan persentase sebesar $79 \%$ tergolong dalam kriteria tinggi. Artinya pelaku IR dalam hal ini merasakan manfaat dari kegiatan yang telah mereka ikuti, terlihat dari tiga item pertanyaan jawaban responden masuk dalam kriteria tinggi. Secara keseluruhan tingkat partisipasi pelaku IR termasuk dalam kriteria sedang. Hal ini sejalan dengan penelitian Kurniawan dan Prihtanti (2018), bahwa partispasi kelopok tani dalam proses budidaya pertanian padi organik termasuk kriteria sedang.

\section{Hubungan Peran Pendamping dengan Partisipasi Pelaku Industri Rumahan}

Hubungan peran pendamping dengan partisipasi pelaku IR merupakan salah satu indikator keberhasilan suatu program pemberdayaan perempuan. Peran pendamping umumnya harus didasari dengan adanya usaha untuk 
memotivasi pelaku IR untuk ikut berpartisipasi dalam kegiatan. Adanya peran pendamping diharapkan mampu mempengaruhi pelaku IR agar ikut berpartisipasi dalam pelaksanaan program yang bertujuan untuk peningkatan kualitas produk dan pengembangan usaha. Pelaku IR harus diberi motivasi agar pelaku IR dapat semangat untuk menciptakan keberhasilan bagi diri, keluarga dan lingkungannya. Hasil penelitian ini menunjukkan bahwa terdapat hubungan positif significat antara tingkat pelaksanaan peran pendamping dengan partisipasi pelaku IR dalam program pemberdayaan perempuan di Kelurahan 27 Ilir dan 30 Ilir Kota Palembang, dengan nilai koefisien korelasi Rs $=620$ pada $a=0,05$. Hal ini berarti $62 \%$ variasi tingkat partisipasi Pelalu IR dapat dijelaskan oleh tingkat peran pendamping. Terdapat kecenderungan semakin tinggi tingkat pelaksanaan peran pendamping maka semakin tinggi pula tingkat partisipasi Pelaku IR dan Program Pemberdayaan Perempuan. Hasil Penelitian ini sejalan dengan penelitian Listiana,dkk (2018) bahwa kapasitas Penyuluh di Provinsi Lampung berada pada katagori sedang, demikian pula kepuasan petani dalam kegiatan penyuluhan juga pada katagori sedang. Tingkat kapasitas penyuluh berhubungan sangat nyata dengan kepuasan petani terhadap kegiatan penyuluhan dengan nilai $\mathrm{Rs}=0,323$. Hal ini juga berarti bahwa pelaksanaan peran penyuluh dalam melaksanakan tupoksinya berhubungan dengan kepuasan petani yang pada akhirnya mempengaruhi partisipasinya dalam kegiatan penyuluhan.

\section{Kesimpulan}

Tingkat peran pendamping dalam mendampingi pelaku Industri Rumahan termasuk kriteria tinggi, dengan skor rata-rata skor rata-rata 115 (capaian 76,67\%). Ini berarti pendamping sudah melakukan tugas dan fungsinya sesuai pedoman yang diberikan.

Tingkat partisipasi pelaku IR dalam mengikuti kegiatan program termasuk kriteria sedang dengan skor ratarata 51 (capaian $64 \%$ ). Secara rinci, partisipasi dalam pengambilan keputusan, partisipasi dalam pelaksanaan kegiatan, partisipasi dalam pemantauan dan evaluasi pembangunan termasuk katagori sedang, dan hanya partisipasi dalam pemanfaatan hasil pembangunan yang dalam katagori tinggi.

Tingkat pelaksanaan peran pendamping berkorelasi positif dengan tingkat partisipasi pelaku Industri Rumahan , dengan nilai koefisien korelasi $\mathrm{Rs}=0,62$ signifikan pada $a=\cdot, 05$.

\section{Ucapan Terimakasih}

Ucapan terima kasih disampaikan pada Universitas Sriwijaya melalui Lembaga Penelitian, yang telah memberikan bantuan dana penelitian, yang mana penelitian ini merupakan bagian dari Penelitian Hibah Profesi tahun 2018. Terimakasih juga disampaikan kepada seluruh responden, key informan, dan stakeholder yang terlibat dalam Program Pemberdayaan (Program Industri Rumahan) yang telah membantu pada terlaksananya penelitian ini.

\section{Daftar Pustaka}

Direktorat Pemberdayaan Perempuan dan Perlindungan Anak. 2016. Pedoman Umum Program Industri Rumahan. Jakarta.

Fitrianti,Nurul.,danSadono,Dwi.(2013).PartisipasiMasyarakat dalam Program Nasional Pemberdayaan MasyarakatMandiri di Desa Kotabatu, Kecamatan Ciomas, Kabupaten Bogor. Jurnal Penyuluhan. V(9)1, 80-87.

Horton, Paul B., dan L. Hunt, Chester. (1991). Sosiologi. Jakarta: Erlangga.

Ife, Jim., dan Tesoriero, Frank. (2008). Community Development. Yogyakarta: Pustaka Pelajar. Levis, L.R. 1996. Komunikasi Penyuluhan Pertanian Pedesaan. PT. Citra Aditing Bakti. Bandung.

Kurniawan, W.Angga., T.M.Prihtanti. 2018. Hjenjang Partisipai dan Determinan Partisipasi Petani dalam Introduksi Budidaya Padi Organik di Desa Pulutan, Kota Sala Tiga. Jurnal Penyuluhan 14 (1): 158-167

Listiana, Indah., Sumardjo, Dwi Sadono, dan Prabowo Tjiptopranoto. 2018. Hubungan Kapasitas Penyuluh dengan Kepuasan Petani dalam Kegiatan Penyuluhan.Jurnal Penyuluhan 14 (2): 244-256.

Mardikanto, Totok. 1993. Penyuluhan Pembangunan Pertanian. Sebelas Maret University Press. Surakarta.

Mardikanto, Totok., dan Soebiato, Poerwoko. (2013). Pemberdayaan Masyarakat Dalam Perspektif Kebijakan Publik. Bandung: Alfabeta.

Ritzer, George. (2012). Teori Sosiologi dari Sosiologi KlasiksampaiPerkembangan TerakhirPostmodern. Yogyakarta: Pustaka Pelajar.

Slamet, Y. 1994. Pembangunan Masyarakat berwawasan Partisipasi. UNS Press. Surakarta.

Umar, Husein. 1999. Metode Penelitian: Aplikasi dalam Pemasaran. Jakarta: PT Gramedia Pustaka Utama. 